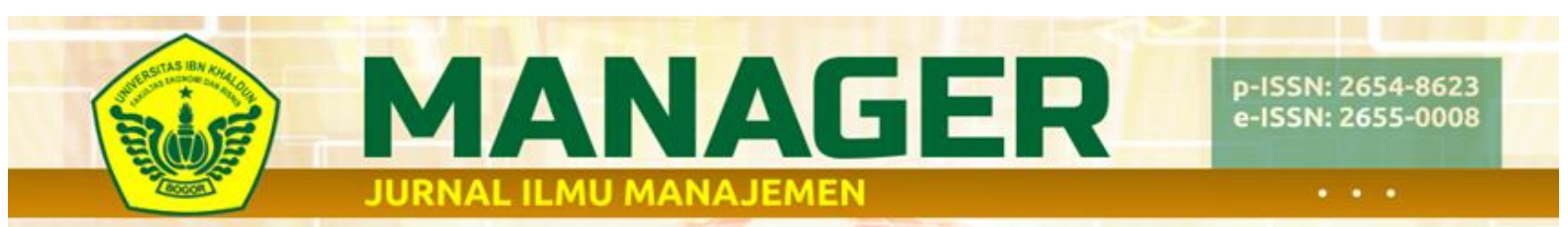

Vol. 3 No 1 Februari 2020 Hal 123-140 @) (1) () (c) http://ejournal.uikabogor.ac.id/index.php/Manager/index

\title{
ANALISIS METODE ECONOMIC VALUE ADDED (EVA) DAN MARKET VALUE ADDED (MVA) UNTUK MENGUKUR KINERJA KEUANGAN
}

\author{
Dini Ramadhanty, Supramono, Diah Yudhawati \\ Fakultas Ekonomi dan Bisnis Universitas Ibn Khaldun Bogor, Indonesia \\ Diniramadhanty29@gmail.com, supramonouika@gmail.com, \\ diahyudhawati@gmail.com,
}

\begin{abstract}
Research with the title Analysis of Economic Value Added (EVA) and Market Value Added (MVA) Methods for Measuring Financial Performance in the Agriculture Sector Food Crop Sub Sector in 2014-2018 aims to determine the company's financial performance if measured using the Economic Value Added (EVA) method and using the Market Value Added (MVA) method at PT Bisi International Tbk, for the 2014-2018 period. The method used in this research is descriptive research. The population as well as the sample in this study is the company PT Bisi International Tbk because there is only one issuer for the food crops sub sector listed on the Indonesia Stock Exchange. The results of this study indicate that PT Bisi International Tbk, has been able to produce economic added value for the company seen from the positive EVA value for 5 periods 2014-2018. PT Bisi International Tbk, is able to produce positive MVA values so that the company PT Bisi International Tbk, can provide market added value to the company and provide wealth for investors.
\end{abstract}

Keywords: Economic Value Added (EVA), Market Value Added (MVA) and Financial Performance.

\begin{abstract}
Abstrak
Penelitian dengan judul Analisis Metode Economic Value Added (EVA) Dan Market Value Added (MVA) Untuk Mengukur Kinerja Keuangan Pada Sektor Pertanian Sub Sektor Tanaman Pangan Tahun 2014-2018 bertujuan untuk mengetahui kinerja keuangan perusahaan jika diukur dengan menggunakan metode Economic Value Added (EVA) dan menggunakan metode Market Value Added (MVA) pada PT Bisi International Tbk, periode 2014-2018. Metode yang digunakan dalam penelitian ini adalah penelitian deskriptif. Populasi sekaligus sampel dalam penelitian adalah perusahaan PT Bisi international Tbk dikarenakan hanya ada satu emiten untuk sub sektor tanaman pangan yang terdaftar dalam Bursa Efek Indonesia. Hasil penelitian ini menunjukan bahwa PT Bisi International Tbk, sudah mampu menghasilkan nilai tambah ekonomis bagi perusahaan dilihat dari nilai EVA positif selama 5 periode 2014-2018. PT Bisi International Tbk, mampu menghasilkan nilai MVA yang positif sehingga perusahaan PT Bisi International Tbk, dapat memberikan nilai tambah pasar pada perusahaan serta memberikan kekayaan bagi investor.
\end{abstract}

Kata Kunci : Economic Value Added (EVA), Market Value Added (MVA) dan Kinerja Keuangan. 


\section{Pendahuluan}

\section{Latar Belakang}

Pertanian adalah kegiatan pemanfaatan sumber daya hayati yang dilakukan manusia untuk menghasilkan bahan pangan, bahan baku industri, atau sumber energi, serta untuk mengelola lingkungan hidupnya. Kegiatan pemanfaatan sumber daya hayati yang termasuk dalam pertanian biasa difahami orang sebagai budidaya tanaman atau bercocok tanam (crop cultivation) serta pembesaran hewan ternak (raising), meskipun cakupannya dapat pula berupa pemanfaatan mikroorganisme dan bioenzim dalam pengolahan produk lanjutan, seperti pembuatan keju dan tempe, atau sekedar ekstraksi semata, seperti penangkapan ikan atau eksploitasi hutan. Sektor pertanian merupakan sektor yang mempunyai peranan strategis dalam struktur pembangunan perekonomian nasional.

Sub sektor tanaman pangan bagian dari sektor pertanian memiliki peranan sangat penting dalam ketahanan nasional, mewujudkan ketahanan pangan, pembangunan wilayah, pengentasan kemiskinan, penyerapan tenaga kerja, dan penerimaan devisa, serta menjadi penarik bagi pertumbuhan industri hulu dan pendorong pertumbuhan industri hilir yang memberikan kontribusi cukup besar terhadap pertumbuhan ekonomi nasional. Peranan tanaman pangan telah terbukti secara empiris, baik dikala kondisi ekonomi normal maupun saat menghadapi krisis. Pertanian tanaman pangan sangat relevan untuk dijadikan sebagai pilar ekonomi didaerah, mengingat sumber daya ekonomi yang dimiliki setiap daerah yang siap didayagunakan untuk membangun ekonomi daerah adalah sumber daya pertanian tanaman pangan, seperti sumber daya alam (lahan, air, keragaman hayati, agroklimat). Sub sektor tanaman pangan memegang peranan penting sebagai pemasok kebutuhan konsumsi penduduk, khusus di Indonesia tanaman pangan juga berkedudukan strategis dalam memelihara stabilitas ekonomi nasional.

Secara umum, perusahaan termasuk perusahaan di bidang subsektor tanaman pangan ingin mengembangkan usahanya, dan saat ini cara yang banyak dipilih adalah melalui cara mencari investor untuk berinvestasi di perusahaan mereka. Investasi merupakan suatu kegiatan menempatkan sejumlah dana selama periode tertentu dengan harapan memperoleh penghasilan dan atau peningkatan nilai investasi pada masa yang akan datang. Dalam melakukan kegiatan investasi, investor akan bertindak sangat hati-hati dalam menilai berbagai alternatif investasi yang ada karena investasi yang dilakukan para investor umumnya bukan hanya untuk keuntungan jangka pendek tetapi untuk memperoleh pendapatan jangka panjang. Keuntungan yang ingin diperoleh seorang investor tersebut disamping untuk mendapatkan keuntungan dividen juga untuk mendapatkan capital gain.

Secara umum, return saham pada laporan keuangan yang dipublikasi adalah hal pertama yang dilihat calon investor sebelum berinvestasi. Tanpa adanya return saham, investor tidak akan berminat untuk berinvestasi karena tujuan utama investor berinvestasi adalah untuk mendapatkan suatu keuntungan atau return. Hingga kini pengukuran kinerja perusahaan lebih dititikberatkan pada rasio-rasio keuangan di dalam suatu laporan keuangan. Karena rasio tersebut sebenarnya sangat penting diperhatikan untuk mengetahui 
sejauhmana investasi yang akan dilakukan investor di suatu perusahaan mampu memberikan return yang sesuai dengan tingkat yang disyaratkan investor.

Namun, penggunaan rasio profitabilitas memiliki kelemahan yaitu tidak memperhatikan risiko yang dihadapi perusahaan dengan mengabaikan adanya biaya modal dan hanya memperhatikan hasilnya (laba), sehingga itu sulit untuk mengetahui apakah perusahaan tersebut telah berhasil menciptakan nilai (value) perusahaan atau tidak. Nilai sebuah perusahaan itu sendiri merupakan acuan penting bagi investor dalam melakukan investasi. Belakangan ini telah berkembang pendekatan baru dalam mengukur kinerja keuangan yang dikenal dengan Economic Value Added (EVA) dan Market Value Added (MVA).

Untuk mengatasi permasalahan pada analisis rasio tersebut, maka muncullah pendekatan baru yang disebut EVA (Economic Value Added) dan MVA (Market Value Added). EVA adalah suatu sistem manajemen keuangan untuk mengukur laba ekonomi dalam suatu perusahaan, yang menyatakan bahwa kesejahteraan hanya dapat tercipta jika perusahaan mampu memenuhi semua biaya operasi (operating cost) dan biaya modal (cost of capital). (Rudianto 2006:340) EVA sebagai indikator dari keberhasilan manajemen dalam memilih dan mengelola sumber-sumber dana yang ada di perusahaan tentunya juga akan berpengaruh positif terhadap return pemegang saham. Di dalam konsep EVA memperhitungkan modal saham, sehingga memberikan pertimbangan yang adil bagi para penyandang dana perusahaan. Selain EVA, ada pendekatan lain yang digunakan juga untuk mengukur kinerja perusahaan yang didasarkan pada nilai pasar.
Perhitungan pada nilai pasar tersebut dikenal dengan istilah MVA (Market Value Added).MVA (Market Value Added) adalah perbedaan antara nilai pasar saham perusahaan dengan jumlah ekuitas modal investor yang telah diberikan. (Brigham \& Houston, 2006, hal. 68)

Berdasarkan latar belakang diatas hal ini menarik untuk melakukan penelitian dengan mengambil judul "Analisis Metode Economic Value Added (EVA) dan Market Value Added (MVA) Untuk Mengukur Kinerja Keuangan Pada Sektor Pertanian Sub Sektor Perkebunan Tahun 2013-2018".

\section{Rumusan Masalah}

1. Bagaimana kinerja keuangan perusahaan PT Bisi Internasional Tbk Tahun 2014-2018 yang terdaftar pada Bursa Efek Indonesia jika diukur dengan menggunakan metode Economic Value Added (EVA)

2. Bagaimana kinerja keuangan perusahaan PT Bisi Internasional Tbk Tahun 2014-2018 yang terdaftar pada Bursa Efek Indonesia jika diukur dengan menggunakan metode Market Value Added (MVA)

\section{Metode Penelitian \\ Desain Penelitian}

Penelitian deskriptif merupakan salah satu cara penelitian dengan menggambarkan serta menginterprestasi suatu objek sesuai dengan kenyataan yang ada. Ciri yang dominan dalam desain penelitian deksriptif ini adalah menjelaskan karakteristik satu variabel tertentu secara terstruktur dan spesifik, dimana data yang dianalisis berupa data sekunder atau hasil observasi tertentu, bertujuan mengetahui kinerja keuangan menggunakan metode 
Economic Value Added (EVA) dan Variabel dan Pengukuran

Penelitian ini menggunakan variabel kinerja keuangan. Dimana pengukuran dilakukan dengan menggunakan metode EVA

\section{Populasi dan Sampel}

Populasi sekaligus sampel dalam penelitian ini adalah perusahaan PT Bisi international Tbk dikarenakan hanya ada satu emiten untuk sub sektor tanaman pangan yang terdaftar dalam Bursa Efek Indonesia.

\section{Sumber Data}

Data Sekunder ini berupa laporan keuangan tahunan serta informasi harga saham dari perusahaanperusahaan sampel yang diperoleh melalui Bursa Efek Indonesia selama 5 periode terakhir. Data laporan keuangan yang akan digunakan dalam penelitian ini adalah laporan laba rugi dan laporan neraca serta data tingkat suku bunga Sertifikasi Bank Indonesia (SBI), Indeks Harga Saham Gabungan (IHSG) serta studi kepustakaan.

\section{Metode Analisis Data}

Analisis data yang digunakan saat pengolahan data dalam penelitiannya adalah data sekunder yang pengolahannya dengan melalui
Market Value Added (MVA).

(Economic Value Added) dan MVA (Market Value Added) bertujuan untuk mengukur komponen-komponen dalam penyusunan kinerja keuangan perusahaan.

\section{Teknik Pengumpulan Data}

Dalam memperoleh data untuk penulisan penelitian ini, penulis menggunakan cara observasi tentang informasi data perusahaan yang ada, dikarenakan data ini bersifat data sekunder yaitu mencari data yang memang tidak terjun langsung keperusahaan tetapi melalui pencarian data atau informasi data yang ada di situs yang ada diinternet lalu bisa dengan cara studi perpustakaan (library research) atau yang diartikan pencarian suatu data yang ingin dikumpulkan dengan cara membaca laporan tahunan dan yang terakhir bisa melihat tulisan ilmiah serta tulisan yang dapat di perpustakaan seperti buku-buku yang ditulis para ahli dibidangnya.

Metode data kuantitatif atau data numeric (angka-angka).

Langkah-langkah dalam menentukan nilai Economic Value Added (EVA) sebagai berikut:

Menghitung Biaya Modal / Cost of Capital (COC)

a) Biaya Modal Dari Hutang $(\mathrm{Kd})$

$$
=\frac{\text { beban bunga }}{\text { total hutang }} \times 100 \%
$$

b) Biaya Modal Sendiri (Ke)

$$
=\frac{\text { laba bersih setelah pajak }}{\text { total equitas }} \times 100 \%
$$

Menghitung Biaya Modal Rata-rata Tertimbang WACC (Ko)

Keterangan: WACC (Ko)

$$
\begin{aligned}
& \text { WACC }=\left(K d^{*} x W e\right)+(\text { Ke } x W d) \\
& \text { Dimana }: \\
& \text { WACC }=\text { Biaya modal rata-rata tertimbang } \\
& \mathrm{Kd}^{*} \quad=\text { Biaya Hutang } \\
& \mathrm{Wd} \quad=\text { Proporsi hutang dalam struktur modal } \\
& \mathrm{Ke} \quad=\text { Biaya Ekuitas }
\end{aligned}
$$


Menghitung EVA

$\mathrm{EVA}=\mathrm{NOPAT}-\mathrm{COC}$

Keterangan:

NOPAT $=$ Laba Bersih Setelah Pajak

$\mathrm{COC}=$ Biaya Modal Biaya modal dari hutang $(\mathrm{Kd})+$ Biaya modal Sendiri (Ke).

Menghitung MVA

\section{Hasil dan Pembahasan}

\section{Economic Value Added (EVA)}

Menurut Husnan \& Pudjiastuti (2015:70) dalam bukunya yang berjudul Dasar-Dasar Manajemen Keuangan menyatakan bahwa Eva menilai efektivitas manajerial untuk satu tahun tertentu.

Konsep EVA berfokus pada penciptaan nilai dari modal yang investor tanamkan dalam operasi perusahaan, perusahaan harus mendapatkan pengembalian atas modal yang diinvestasikan lebih besar dari biaya modalnya. Sedangkan menurut Rahardjo (2005:123) mendefinisikan "EVA sebagai laba usaha dikurangi dengan pajak dan biaya bunga atas hutang serta dikurangi cadangan untuk biaya modal".

\section{Analisis Economic Value Added (EVA)}

Metode EVA bertujuan untuk mengukur kinerja investasi suatu perusahaan sekaligus memperhatikan kepentingan dan harapan penyandang dana yaitu kreditur dan pemegang saham. Dengan metode EVA akan diperoleh perhitungan ekonomis yang aktual karena EVA dihitung berdasarkan biaya modal rata-rata tertimbang.

Economic Value Added merupakan ukuran keberhasilan manajemen perusahaan dalam meningkatkan nilai tambah (value

$$
\begin{aligned}
& \text { MVA = Market of Equity - Equity } \\
& \text { Capital Suplied } \\
& =\text { Equity market Value - Equity } \\
& \text { Book Value }
\end{aligned}
$$

Dimana :

EMV = Number Share $x$ Price Per Share

$E B V=$ Number Share $x$ Nomina Value Per Share

added) perusahaan. jika kinerja manajemen perusahaan baik atau efektif (diketahui dari hasil nilai tambah yang diperoleh), maka harga saham perusahaan akan mengalami peningkatan. Sehingga, jika manajer memfokuskan operasional perusahaan pada EVA sudah pasti akan membantu mereka beroperasi secara konsisten untuk memaksimalkan nilai pemegang saham.

Dalam bab ini seluruh data dianalisis kemudian diolah, data diperoleh dari laporan keuangan di Bursa Efek Indonesia (BEI) atau Indonesia Stock Exchange (IDX), data bulanan Indeks Harga Saham Gabungan (IHSG) periode desember 2012 sampai desember 2018 dan tingkat suku bunga Sertifikat bank Indonesia (SBI) per satu bulanan dari tahun 2014-2018. Berikut perhitungan EVA dan MVA pada PT Bisi International Tbk periode 2013-2018 :

Perhitungan Economic Value Added (EVA)

EVA merupakan alat pengukur kinerja keuangan perusahaan yang menghitung semua biaya modal sehingga dari pengukuran tersebut akan terlihat kemampuan rill perusahaan dalam menciptakan nilai tambah. Berikut langkah langkah yang harus dilakukan sebelum melakukan perhitungan EVA: 
1. Perhitungan NOPAT (Net Operating After Tax)

NOPAT $=$ Laba Bersih + Biaya bunga

Tabel 1

Perhitungan NOPAT PT Bisi International Tbk pada tahun 2014-2018

(Dalam Jutaan Rupiah)

\begin{tabular}{llllll}
\hline Tahun & $\begin{array}{l}\text { Laba } \\
\text { Bersih }\end{array}$ & $\begin{array}{l}\text { Biaya } \\
\text { Bunga }\end{array}$ & NOPAT & Perubahan & $\%$ \\
\hline 2014 & 165.279 & 901 & 166.180 & & \\
\hline 2015 & 263.967 & 947 & 264.914 & 98.734 & $37,3 \%$ \\
\hline 2016 & 336.220 & 930 & 337.150 & 72.236 & $21,4 \%$ \\
\hline 2017 & 403.287 & 78 & 403.365 & 66.215 & $16,4 \%$ \\
\hline 2018 & 403.870 & 1.593 & 405.463 & 2.098 & $0,5 \%$ \\
\hline
\end{tabular}

Sumber : Data Diolah

Pada hasil perhitungan NOPAT di atas, nilai NOPAT dipengaruhi oleh nilai laba bersih dengan beban bunga atau biaya keuangan. Dapat dilihat perhitungan pada PT Bisi International Tbk. Pada tahun 2014 sampai 2018 perusahaan tersebut mengalami perubahan laba bersih setelah pajak (NOPAT), pada tahun 2015 mengalami perubahan sebesar $37,3 \%$ dari Rp. 166.180 pada tahun 2014 menjadi Rp.
264.914 pada tahun 2015, pada tahun 20167 mengalami perubahan sebesar 21,4\% dari Rp. 264.914 pada tahun 2015 menjadi Rp. 337.150 pada tahun 2016, dan pada tahun 2017 mengalami perubahan sebesar 16,4\% dari Rp. 337.150 pada tahun tahun 2016 menjadi Rp. 66.215 pada tahun 2017. Terjadi perubahan pada tahun 2018 sebesar 0,5\% dari Rp. 66.215 menjadi Rp. 2.098.

2. Perhitungan tingkat pengembalian pasar $(R m t)$ dan tingkat pengembalian pasar rata-rata $(R m)$.

$$
R m t=\frac{I H S G t-I H S G t-1}{I H S G t-1}
$$

Tabel 2

Perhitungan tingkat pengembalian pasar $(R m t)$ dan tingkat pengembalian pasar rata-rata (Rm) Tahun 2014-2018

\begin{tabular}{|c|c|c|c|c|c|}
\hline \multirow{2}{*}{ Bulan } & \multicolumn{5}{|c|}{$R m t$} \\
\hline & 2014 & 2015 & 2016 & 2017 & 2018 \\
\hline Januari & 0,0338 & 0,0119 & 0,0048 & $\begin{array}{c}- \\
0,0004 \\
\end{array}$ & 0,0393 \\
\hline Februari & 0,2718 & 0,0304 & 0,0337 & 0,0174 & $-0,0012$ \\
\hline Maret & $-0,1515$ & 0,0125 & 0,0155 & 0,0336 & $-0,0618$ \\
\hline April & 0,0150 & $\begin{array}{c}- \\
0,0783 \\
\end{array}$ & $\begin{array}{c}- \\
0,0014 \\
\end{array}$ & 0,0005 & $-0,0314$ \\
\hline Mei & 0,0111 & 0,0255 & $\begin{array}{c}- \\
0,0086 \\
\end{array}$ & 0,0305 & $-0,0018$ \\
\hline Juni & $-0,0031$ & $\begin{array}{c}- \\
0,0586 \\
\end{array}$ & 0,0458 & 0,0188 & $-0,0308$ \\
\hline
\end{tabular}




\begin{tabular}{lccccc} 
Juli & 0,0430 & 0,0220 & 0,0397 & 0,0009 & 0,0236 \\
\hline Agustus & 0,0094 & 0,0609 & 0,0326 & 0,0039 & 0,0138 \\
\hline September & 0,0001 & 0,0633 & 0,0039 & 0,0062 & $-0,0069$ \\
\hline Oktober & $-0,0093$ & 0,0547 & 0,0107 & 0,0177 & $-0,0242$ \\
\hline November & 0,0118 & 0,0019 & 0,0504 & 0,0089 & 0,0384 \\
\hline Desember & 0,0149 & 0,0329 & 0,0287 & 0,0677 & 0,0228 \\
\hline & & - & & & \\
Rata-rata $(\mathrm{Rm})$ & 0,0205 & 0,0097 & 0,0122 & 0,0155 & $-0,0016$ \\
\hline
\end{tabular}

Sumber : Data diolah

3. Perhitungan rata-rata tingkat suku bunga Sertifikat Bank Indonesia

Risk Free (Rf) merupakan rata-rata tingkat pengembalian bebas risiko suku bunga Sertifikat Bank Indonesia (SBI). Rata-rata Risk Free (Rf) didapat dari tingkat suku bunga Sertifikat Bank Indonesia (SBI) bulanan yang dijumlahkan dan dihitung untuk mendapatkan nilai rata-rata Rata-rata Risk Free (Rf) tahunan.

4. Perhitungan tingkat pengembalian saham bulanan
(Rit) dan tingkat pengembalian saham rata-rata (Ri) Rit $=\frac{\mathrm{P}_{\mathrm{it}}-\mathrm{P}_{\mathrm{it}-1}}{\mathrm{P}_{\mathrm{it}-1}}$

Dimana :

Rit $=$ Tingkat pengembalian saham ke-I pada bulan ke-i

Pit = Harga penutup saham pada bulan ke-t untuk perusahaan ke-i

Pit-1 = Harga penutup saham pada bulan sebelumnya ( $\mathrm{t}-1)$ untuk perusahaan ke-i $\mathrm{Rt}=$ Tingkat pengembalian saham rata-rata

Tabel 3

Perhitungan tingkat pengembalian saham bulanan (Rit) dan tingkat pengembalian saham rata-rata (Rt) PT Bisi International Tbk. Tahun 2014-2015

$\begin{array}{lll}\text { Periode } 2013 & 2014\end{array}$

\begin{tabular}{|c|c|c|c|c|c|c|c|}
\hline Bulan & Pit & Pit & Pit-1 & Rit & Pit & Pit-1 & Rit \\
\hline Januari & & 530 & 560 & $-0,0535$ & 1.050 & 790 & 0,3291 \\
\hline Februari & & 650 & 530 & 0,2264 & 1.075 & 1.050 & 0,0238 \\
\hline Maret & & 660 & 650 & 0,0153 & 1.310 & 1.075 & 0,2186 \\
\hline April & & 615 & 660 & $-0,0681$ & 1.400 & 1.310 & 0,0687 \\
\hline Mei & & 545 & 615 & $-0,1138$ & 1.690 & 1.400 & 0,2071 \\
\hline Juni & & 520 & 545 & $-0,0458$ & 1.600 & 1.690 & - \\
\hline
\end{tabular}




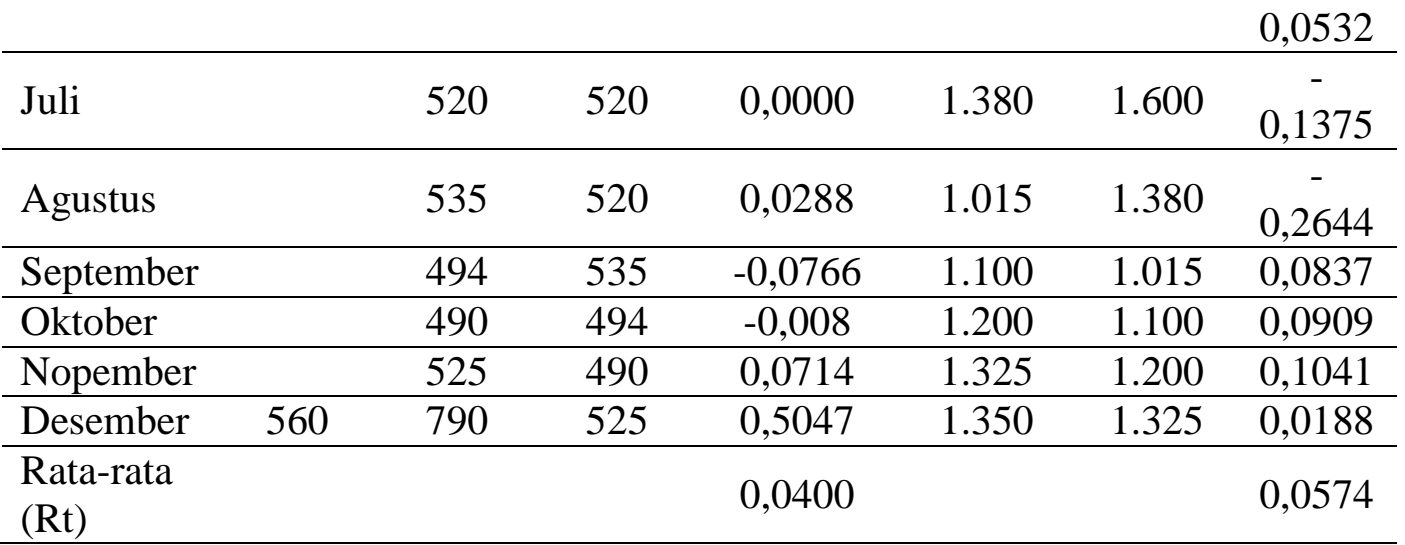

Sumber : Data Diolah

Tabel 4

Periode

\begin{tabular}{lcccccc}
\hline \multicolumn{1}{c}{ Bulan } & Pit & Pit-1 & Rit & Pit & Pit-1 & Rit \\
\hline Januari & 1.270 & 1.350 & $-0,0592$ & 1.805 & 1.900 & $-0,05$ \\
\hline Februari & 1.445 & 1.270 & 0,1377 & 1.710 & 1.805 & $-0,0526$ \\
\hline Maret & 1.765 & 1.445 & 0,2214 & 1.880 & 1.710 & 0,0994 \\
\hline April & 1.665 & 1.765 & $-0,0566$ & 1.860 & 1.880 & $-0,0106$ \\
\hline Mei & 1.750 & 1.665 & 0,0510 & 1.665 & 1.860 & $-0,1048$ \\
\hline Juni & 1.750 & 1.750 & 0,0000 & 1.620 & 1.665 & $-0,0270$ \\
\hline Juli & 1.760 & 1.750 & 0,0057 & 1.530 & 1.620 & $-0,0555$ \\
\hline Agustus & 1.760 & 1.760 & 0,0000 & 1.460 & 1.530 & $-0,0457$ \\
\hline September & 1.800 & 1.760 & 0,0227 & 1.515 & 1.460 & 0,0376 \\
\hline Oktober & 2.000 & 1.800 & 0,1111 & 1.640 & 1.515 & 0,0825 \\
\hline Nopember & 1.825 & 2.000 & $-0,0875$ & 1.650 & 1.640 & 0,0060 \\
\hline Desember & 1.900 & 1.825 & 0,0410 & 1.795 & 1.650 & 0,0878 \\
\hline Rata-rata & & & & & $-0,0027$ \\
(Rt) & & 0,3229 & & & \\
\hline
\end{tabular}

Tabel 5

Perhitungan tingkat pengembalian saham bulanan (Rit) dan tingkat pengembalian saham rata-rata $(R t)$ PT Bisi International Tbk. Tahun 2018

\begin{tabular}{lccc}
\hline \multicolumn{1}{c}{ Periode } & & 2018 & \\
& & & \\
\hline Bulan & Pit & Pit-1 & Rit \\
\hline Januari & 1.755 & 1.795 & $-0,0222$ \\
\hline Februari & 1.780 & 1.755 & 0,0142 \\
\hline Maret & 1.975 & 1.780 & 0,1095 \\
\hline April & 1.910 & 1.975 & $-0,0329$ \\
\hline
\end{tabular}




\begin{tabular}{llll} 
Mei & 1.875 & 1.910 & $-0,0183$ \\
\hline Juni & 1.725 & 1.875 & $-0,0800$ \\
\hline Juli & 1.740 & 1.725 & 0,0086 \\
\hline Agustus & 1.420 & 1.740 & $-0,1839$ \\
\hline September & 1.700 & 1.420 & 0,1971 \\
\hline Oktober & 1.450 & 1.700 & $-0,147$ \\
\hline Nopember & 1.570 & 1.450 & 0,0827 \\
\hline Desember & 1.675 & 1.570 & 0,0668 \\
\hline $\begin{array}{l}\text { Rata-rata } \\
\text { (Rt) }\end{array}$ & & & \\
\hline
\end{tabular}

5. Perhitungan Varian

Varian atau ragam suatu perubahan acak atau distribusi probabilitas adalah ukuran bagi persebaran data. Adapun hal yang diukur adalah perubahan seberapa jauh data tersebar di retata. Variabel merupakan salah satu parameter bagi distribusi normal akar dari varian dikenal sebagai simpangan baku (standar deviasi) Rumu Varian :

$$
\sigma^{2} m=\frac{\Sigma^{n}\left(R_{m t}-R_{m}\right)^{2}}{n-1}
$$

Dimana :

$R m t=$ Tingkat pengembalian pasar bulan $\mathrm{t}$

$R m=$ Tingkat pengembalian pasar rata-rata

$n=$ Jumlah periode

Tabel 6

Hasil Varian Tahun 2014-2018

\begin{tabular}{cc}
\hline Tahun & Varian $(\sigma 2 m)$ \\
\hline 2014 & 0,0086 \\
\hline 2015 & 0,0026 \\
\hline 2016 & 0,0007 \\
\hline 2017 & 0,0004 \\
\hline 2018 & 0,0009 \\
\hline
\end{tabular}

Sumber : Data diolah

Nilai varian didapat dari tingkat pengembalian pasar yang dihitung dari Indeks Harga Saham Gabungan (IHSG) tahun 2014-2018. Dari tabel diatas dapat diketahui nilai varian per tahun. Maka nilai rata-rata varian yang di peroleh pada tahun 2014 sebesar 0,0086, tahun 2015 sebesar 0,0026, tahun 2016 sebesar 0,0007, tahun 2017 sebesar 0,0004, tahun 2018 sebesar 0,0009.

6. Perhitungan Kovarian

Kovarian adalah ukuran dari seberapa banyak dua set data yang berbeda-beda. Kovarian menentukan sejauh mana dua variabel yang berkaitan atau bagaimana mereka bervariasi bersama. 
Kovarian adalah rata-rata hasil dari penyimpangan titik data masing-masing.

$$
\sigma i m=
$$$$
\frac{\sum_{i=t}^{n}\left(R_{i t}-R_{t}\right)\left(R_{m t}-R_{m}\right)}{n}
$$

Dimana :

Tabel 7

\begin{tabular}{cc}
\hline Tahun & $\begin{array}{c}\text { Kovarian } \\
\text { (øim) }\end{array}$ \\
\hline 2014 & 0,0045 \\
\hline 2015 & 0,003 \\
\hline 2016 & 0,0007 \\
\hline 2017 & 0,0005 \\
\hline 2018 & 0,0004 \\
\hline
\end{tabular}

Dari perhitungan diatas, dapat nilai kovarian berdasarkan tingkat pengembalian saham yang dihitung dari harga saham PT Bisi international Tbk. Pada lima tahun terakhir. Nilai ratarata kovarian yang diperoleh pada tahun 2014 sebesar 0,0045, tahun 2015 sebesar 0,0030 lalu pada tahun 2016 sebesar 0,0007, tahun 2017 sebesar 0,0005 dan tahun terakhir yaitu tahun 2018 sebesar 0,0004 .

7. Perhitungan Beta

$$
\beta=\sigma \mathrm{i}_{\mathrm{m}} / \sigma_{\mathrm{m}}^{2}
$$

Dimana :

$$
\begin{aligned}
& \beta=\text { Beta } \\
& \sigma \mathrm{i}_{\mathrm{m}}=\text { Kovarian } \\
& \sigma_{\mathrm{m}}^{2}=\text { Varian }
\end{aligned}
$$

Nilai Beta didapat dari nilai Kovarian pertahun dibagi nilai Varian pertahun
Rit $=$ Tingkat pengembalian saham bulan $\mathrm{t}$

$R t=$ Tingkat pengembalian saham rata-rata

$R m t=$ Tingkat pengembalian pasar bulan $\mathrm{t}$

$R m=$ Tingkat pengembalian pasar rata-rata maka akan diketahui nilai Beta. Dapat dilihat dari perhitungan tabel diatas nilai Beta pada tahun 2014 sebesar 0,5232, tahun 2015 sebesar 1,1538, Pada tahun 2016 nilai beta sebesar 1,0000, tahun 2017 sebesar 1,2500 , dan pada periode terakhir tahun 2018 sebesar 0,4444. PT Bisi International Tbk, mengalami perubahan nilai Beta selama periode 2014-2018 adalah masingmasing sebesar 54,6\%,$15,38 \%, 20 \%$, dan $-181,2 \%$.

8. Perhitungan Biaya Hutang $\left(K d^{*}\right)$

$\mathrm{Kd}^{*}=\mathrm{Kd}(1-\mathrm{t})$

$K d=\frac{\text { Biaya Bunga }}{\text { Total Hutang }}$

$t=\frac{\text { Pajak Bunga }}{\text { Laba Sebelum Pajak }}$

Dimana :

$\mathrm{Kd}=$ Biaya Hutang

$\mathrm{t} \quad=$ Pajak

$\mathrm{Kd}^{*}=$ Biaya Hutang 
Tabel 8

Perhitungan Biaya Hutang ( $\left.K d^{*}\right)$ PT Bisi International Tbk. Tahun 2014-2018

(Dalam Jutaan Rupiah)

\begin{tabular}{|c|c|c|c|c|c|}
\hline \multirow[t]{2}{*}{ Tahun } & Biaya Bunga & $\begin{array}{c}\text { Jumlah } \\
\text { Hutang } \\
\text { Jangka } \\
\text { Panjang }\end{array}$ & $\begin{array}{c}\text { Kd } \\
\text { (biaya } \\
\text { hutang) }\end{array}$ & \multirow[t]{2}{*}{$\begin{array}{l}\text { Beban } \\
\text { Pajak }\end{array}$} & \\
\hline & (a) & (b) & $\begin{array}{l}\text { (c) }= \\
\text { (a)/(b) }\end{array}$ & & \\
\hline 2014 & 901 & 54.900 & 0,0164 & 43.873 & \\
\hline 2015 & 947 & 47.060 & 0,0201 & 67.626 & \\
\hline 2016 & 930 & 51.128 & 0,0181 & 117.875 & \\
\hline 2017 & 78 & 59.976 & 0,0013 & 115.910 & \\
\hline 2018 & 1.593 & 59.962 & 0,0265 & 101.629 & \\
\hline Tahun & $\begin{array}{l}\text { Kd (biaya } \\
\text { hutang) }\end{array}$ & Pajak (t) & $1-\mathrm{t}$ & $\begin{array}{c}\mathrm{Kd}^{*}=\mathrm{kd} \mathrm{x} \\
\quad(1-\mathrm{t})\end{array}$ & $(\%)$ \\
\hline 2014 & 0,0164 & 0,2097 & 0,7903 & 0,0130 & $1,3 \%$ \\
\hline 2015 & 0,0201 & 0,2039 & 0,7961 & 0,0160 & $1,6 \%$ \\
\hline 2016 & 0,0181 & 0,2595 & 0,7405 & 0,0134 & $1,34 \%$ \\
\hline 2017 & 0,0013 & 0,2232 & 0,7768 & 0,0010 & $0,1 \%$ \\
\hline 2018 & 0,0265 & 0,201 & 0,7990 & 0,0212 & $2,12 \%$ \\
\hline
\end{tabular}

Sumber : Data diolah

Berdasarkan hasil perhitungan dalam biaya hutang PT Bisi International Tbk, pada tahun 2014 sebesar 1,3\% ini merupakan biaya yang harus ditanggung oleh perusahaan karena menggunakan dana dari hutang jangka panjang sebesar Rp. 54.900 , pada tahun 2015 biaya hutang sebesar 1,6\% merupakan biaya yang harus di tanggung perusahaan menggunakan dana hutang jangka panjang sebesar Rp. 47.060, untuk tahun 2016 biaya hutang sebesar $1,34 \%$ biaya yang harus ditanggung karena menggunakan dana dari hutang jangka panjang sebesar $0,1 \%$ ini merupakan biaya yang harus ditanggung karena menggunakan dana dari hutang jangka panjang sebesar Rp. 59.976 dan pada tahun 2018 biaya hutang sebesar 2,12 ini merupakan biaya yang harus ditanggung karena menggunakan dana dari hutang jangka panjang sebesar Rp. 59.962.

9. Perhitungan Biaya Modal Saham (Ekuitas)

Biaya modal saham adalah tingkat pengembalian minimum yang diharapkan oleh pemegang saham perusahaan dalam investasinya. $\mathrm{Ke}=$ $\mathrm{Rf}+\beta(\mathrm{Rm}-\mathrm{Rf})$ 
Dimana :

$\mathrm{Ke} \quad$ = Biaya modal saham

$R f=$ Tingkat pengembalian saham $\beta=$ Tingkat risiko

MRP $=$ Premi risiko pasar

Tabel 9

Perhitungan Biaya Modal Saham (Ke) PT Bisi International Tbk. Tahun 2014-2018

\begin{tabular}{|c|c|c|c|c|c|c|c|c|c|}
\hline Tahun & $\mathrm{Rm}$ (a) & $\%$ & Beta & $\operatorname{Rf}(b)$ & $\%$ & $\begin{array}{c}\text { MRP } \\
\{(a)-(b)\}\end{array}$ & $\begin{array}{c}\text { Beta } x \\
\text { MRP } \\
\text { (c) }\end{array}$ & $\begin{array}{c}\mathrm{Ke} \\
\{(\mathrm{b})+ \\
(\mathrm{c})\}\end{array}$ & $\%$ \\
\hline 2014 & 0,0205 & $2,05 \%$ & 0,5232 & 0,0754 & $7,54 \%$ & $-0,0549$ & $-0,0287$ & 0,0467 & $4,67 \%$ \\
\hline 2015 & $-0,0097$ & $-0,97 \%$ & 1,1538 & 0,0752 & $7,52 \%$ & $-0,0849$ & $-0,0980$ & $-0,0228$ & $-2,28 \%$ \\
\hline 2016 & 0,0122 & $1,22 \%$ & 1,0000 & 0,0600 & $6,00 \%$ & $-0,0478$ & $-0,0478$ & 0,0122 & $1,22 \%$ \\
\hline 2017 & 0,0155 & $1,55 \%$ & 1,2500 & 0,0456 & $4,56 \%$ & $-0,0301$ & $-0,0376$ & 0,0080 & $0,80 \%$ \\
\hline 2018 & $-0,0016$ & $-0,16 \%$ & 0,4444 & 0,0510 & $5,10 \%$ & $-0,0526$ & $-0,0234$ & 0,0276 & $2,76 \%$ \\
\hline
\end{tabular}

Sumber : Data diolah

Pada periode 2014-2018 perhitungan ( $\mathrm{Rm})$ pada PT Bisi International Tbk adalah $2,05 \%,-0,97 \%, 1,22 \%, 1,55 \%,-0,16 \%$. Rata-rata tingkat suku bunga SBI perbulan pada tahun 2014-2018 masing-masing adalah sebesar 7,54\%, 7,52\%, 6,00\%, $4,56 \%$, 5,10\%. Dari hasil tingkat pengembalian pasar dan suku bunga SBI diatas, maka diperoleh biaya modal saham (Ke) masing-masing sebesar 4,67\%, $2,28 \%, 1,22 \%, 0,80 \%, 2,76 \%$.

10. Perhitungan Struktur Modal

Perhitungan struktur modal bertujuan untuk mencari nilai $W d$ dan $W e$, struktur modal optimal suatu perusahaan merupakan presentasi seimbang antara komponen hutang dan komponen ekuitas yang dimiliki perusahaan.

$$
\begin{aligned}
W d & =\frac{\text { Total Hutang }}{\text { Aset }} \\
W e & =\frac{\text { Ekuitas }}{\text { Aset }}
\end{aligned}
$$

Dimana :

$W d=$ Proporsi hutang dalam struktur modal $W e=$ Proporsi saham dalam struktur modal

Tabel 10

Perhitungan Struktur Modal PT Bisi International Tbk. Tahun 2014-2018

(Dalam Jutaan Rupiah)

\begin{tabular}{cccccc}
\hline Tahun & Total Hutang (a) & Equitas (b) & Asset ( c $)$ & $\begin{array}{c}\mathrm{Wd}(\mathrm{d})= \\
\text { (a)/(c ) }\end{array}$ & $\begin{array}{c}\mathrm{We}(\mathrm{e})= \\
(\mathrm{b}) /(\mathrm{c})\end{array}$ \\
\hline 2014 & 266.019 & 1.605 .024 & 1.871 .043 & 0,1422 & 0,8578 \\
\hline 2015 & 326.304 & 1.815 .296 & 2.141 .600 & 0,1524 & 0,8476 \\
\hline 2016 & 352.652 & 2.063 .525 & 2.416 .177 & 0,1460 & 0,8540 \\
\hline
\end{tabular}




\begin{tabular}{llllll}
\hline 2017 & 422.226 & 2.200 .110 & 2.622 .336 & 0,1610 & 0,8390 \\
\hline 2018 & 455.080 & 2.309 .930 & 2.765 .010 & 0,1646 & 0,8354 \\
\hline
\end{tabular}

Sumber : Data diolah

11. Perhitungan Weighted Average Cost Of Capital (WACC)

WACC merupakan penjumlahan antara modal saham dan cadangan modal yang dimilliki oleh perusahaan, saldo laba tidak diperhitungkan dalam nilai ekuitas, karena saldo laba hanya menunjukan besarnya laba yang mampu diperoleh perusahaan pada tahun yang bersangkutan dan masih merupakan laba yang belum dicadangkan perusahaan.

$W A C C=\left(K d^{*} x W e\right)+($ Ke $x W d)$

Dimana :

WACC = Biaya modal rata-rata tertimbang

$\mathrm{Kd}^{*}=$ Biaya Hutang

$\mathrm{Wd}=$ Proporsi hutang dalam struktur modal

$\mathrm{Ke}=$ Biaya Ekuitas

Tabel 11

Perhitungan WACC PT Bisi International Tbk. Tahun 2014-2018

\begin{tabular}{ccccccccr}
\hline & \multicolumn{2}{c}{ Struktur Modal } & $\mathrm{Kd}^{*}$ & $\mathrm{Ke}$ & $(\mathrm{wd})(\mathrm{kd} *)$ & $(\mathrm{We})(\mathrm{Ke})$ & WACC & \multirow{2}{*}{$\%$} \\
\cline { 2 - 9 } Tahun & $\mathrm{Wd}$ & $\mathrm{We}$ & $\mathrm{C}$ & $\mathrm{D}$ & $\mathrm{E}$ & $\mathrm{f}$ & $(\mathrm{e})+(\mathrm{f})$ & \\
\hline 2014 & 0,1422 & 0,8578 & 0,0130 & 0,0467 & 0,0018 & 0,0401 & 0,0419 & 4,19 \\
\hline 2015 & 0,1524 & 0,8476 & 0,0160 & $-0,0228$ & 0,0024 & $-0,0193$ & $-0,0169$ & $-1,69$ \\
\hline 2016 & 0,1460 & 0,8540 & 0,0134 & 0,0122 & 0,0020 & 0,0104 & 0,0124 & 1,24 \\
\hline 2017 & 0,1610 & 0,8390 & 0,0010 & 0,0080 & 0,0002 & 0,0067 & 0,0069 & 0,69 \\
\hline 2018 & 0,1646 & 0,8354 & 0,0212 & 0,0276 & 0,0035 & 0,0231 & 0,0265 & 2,65 \\
\hline
\end{tabular}

Sumber : Data diolah (Lampiran 26

Pada perhitungan tabel diatas perusahaan PT Bisi Interntional Tbk. Memiliki nilai rata-rata biaya modal tertimbang (WACC) selama periode 2014-2018 adalah masing-masing sebesar $4,19 \%,-1,69 \%, 1,24 \%$, $0,069 \%, 2,65 \%$. Adanya perubahan nilai WACC dalam periode 2014-2018 disebabkan oleh perubahan proporsi hutang ekuitas. Pada tahun 2015 mengalami penurunan nilai WACC sebesar $\quad-1,69 \%$ dikarenakan perubahan biaya ekuitas pada tahun tersebut.
12. Perhitungan Invested Capital (IC)

Invested Capital (IC) adalah jumlah seluruh pinjaman perusahaan diluar pinjaman jangka pendek tanpa bunga, seperti hutang dagang dan hutang pajak. IC akan menghasilkan Cost of Capital (COC). IC dihitung melalui pengurangan dengan ekuitas yang merupakan pinjaman jangka pendek dan pinjaman jangka panjang.

$\mathrm{IC}=($ Ekuitas + Hutang Jangka Panjang) - Hutang Beban 
Tabel 12

Perhitungan Invested Capital (IC) PT Bisi International Tbk. Tahun 2014-2018

(Dalam Jutaan Rupiah)

\begin{tabular}{cccccc}
\hline Tahun & Equitas & $\begin{array}{c}\text { Hutang } \\
\text { Jangka } \\
\text { Panjang }\end{array}$ & $\begin{array}{c}\text { Hutang } \\
\text { Beban }\end{array}$ & IC & $\%$ \\
\hline 2014 & 1.605 .024 & 54.900 & 107.663 & 1.552 .261 & \\
\hline 2015 & 1.815 .296 & 47.060 & 144.020 & 1.718 .336 & $9,7 \%$ \\
\hline 2016 & 2.063 .525 & 51.128 & 159.594 & 1.955 .059 & $12,1 \%$ \\
\hline 2017 & 2.200 .110 & 59.976 & 177.342 & 2.082 .744 & $6,1 \%$ \\
\hline 2018 & 2.309 .930 & 59.962 & 109.198 & 2.260 .694 & $7,9 \%$ \\
\hline
\end{tabular}

Sumber : Data diolah (Lampiran 27)

Modal yang diinvestasikan (IC) PT Bisi International Tbk, selama 5 tahun periode mengalami perubahan sebesar 9,7\% dari Rp.1.552.261 pada tahun 2014 menjadi Rp. 1.718 .336 pada tahun 2015, pada tahun 2016 sebesar $12,1 \%$ dari Rp.1.718.336 pada tahun 2015 menjadi Rp. 1.955.059 pada tahun 2016. Pada tahun 2017 mengalami sebesar $6,1 \%$ dari $\mathrm{Rp}$. 1.955.059 menjadi Rp. 2.082.744 pada tahun 2017. Dan pada tahun 2018 mengalami perubahan sebesar 7,9\% dari Rp. 2.082 .744 menjadi Rp. 2.260.694
13. Perhitungan Biaya Modal (Cost of Capital)

Biaya modal adalah tingkat pengembalian minimum atas modal yang dibutuhkan untuk mengganti pinjaman dan ekuitas investor.

$\mathrm{COC}=\mathrm{WACC} \mathrm{x}$ IC

Dimana :

COC = Biaya Modal

WACC $=$ Biaya modal rata-rata

tertimbang

IC = Modal yang diinvestasikan

Tabel 13

Perhitungan Biaya Modal COC PT Bisi International Tbk. Tahun 2014-2018

(Dalam Jutaan Rupiah)

\begin{tabular}{ccccc}
\hline Tahun & WACC & IC & COC & $\begin{array}{c}\text { Perubahan } \\
(\%)\end{array}$ \\
\hline 2014 & 0,0419 & 1.552 .261 & 65.039 .735 & $(1.718 .336$ \\
\hline 2015 & $-0,0169$ & -29.039 .878 & $323,9 \%$ \\
\hline 2016 & 0,0124 & 1.955 .059 & 24.242 .731 & $219,8 \%$ \\
\hline 2017 & 0,0069 & 2.082 .744 & 14.370 .933 & $-68,6 \%$ \\
\hline 2018 & 0,0265 & 2.260 .694 & 59.908 .391 & $76,01 \%$ \\
\hline
\end{tabular}

Sumber : Data diolah 
Dari perhitungan tabel diatas dapat dilihat nilai Cos of Capital (COC) pada tahun 2014 sampai 2015 mengalami perubahan sebesar $323,9 \%$, pada tahun 2016 perubahan sebesar 219,8\%, pada tahun 2017 perubahan sebesar $-68,6 \%$ dan pada tahun 2018 mengalami perubahan sebesar $76,01 \%$.

14. Perhitungan Economic Value Added (EVA)

Nilai EVA didapatkan dari selisih antara NOPAT dan COC. EVA yang positif menunjukan penciptaan nilai (Value Corection) sedangkan EVA yang negatif menunjukan penghancuran nilai (Value Destruction).

$\mathrm{EVA}=\mathrm{NOPAT}-\mathrm{COC}$

Dimana :

$\mathrm{EVA}=$ Economic Value Added

NOPAT $=$ Net Operating Profit After Tax (laba operasional bersih setelah pajak ditambah biaya bunga)

$\mathrm{COC}=$ Cost of Capital (biaya modal)

Tabel 14

Perhitungan EVA PT Bisi International Tbk. Tahun 2014-2018

\begin{tabular}{ccccc}
\hline Tahun & NOPAT & COC & EVA & Perubahan \\
\hline 2014 & 166.180 & $65.039,74$ & $101.140,265$ & \\
\hline 2015 & 264.914 & $-29.039,88$ & $293.953,878$ & $65,5 \%$ \\
\hline 2016 & 337.150 & $24.242,73$ & $312.907,269$ & $6,05 \%$ \\
\hline 2017 & 403.365 & $14.370,93$ & $388.994,067$ & $19,5 \%$ \\
\hline 2018 & 405.463 & $59.908,39$ & $345.554,609$ & $-12,5 \%$ \\
\hline
\end{tabular}

Sumber : Data diolah

Berdasarkan hasil analisis dari laporan keuangan PT Bisi International, Tbk memiliki nilai EVA pada tahun 2014 sebesar Rp. 101.140,265., pada tahun 2015 sebesar Rp. 293.953,878 dan mengalami perubahan EVA sebesar 65,5\%, pada tahun 2016 nilai EVA sebesar Rp. 312.907,269 adanya perubahan sebesar $6,05 \%$, pada tahun 2017 sebesar Rp. 388.994,067 dan mengalami perubahan sebesar $19,5 \%$, tahun 2018 EVA sebesar Rp. 345.554,609 mengalami perubahan sebesar $-12,5 \%$. Nilai EVA yang positif menunjukan bahwa adanya proses pertambahan nilai ekonomis bagi pemegang saham dan investor di dalam perusahaan, ini berarti laba yang dihasilkan perusahaan sudah melebihi harapan para investor dan perusahaan dapat mengembalikan pinjaman kreditur. Sebaliknya jika nilai EVA negatif menunjukan tidak adanya proses pertambahan nilai ekonomis bagi pemegang saham dan investor di dalam perusahaan, ini berarti laba yang dihasilkan perusahaan belum maksimal atau melebihi harapan para pemegang saham dan investor.

\section{Market Valued Added (MVA)}

Menurut Husnan \& Pudjiastuti, (2004:65) Kekayaan pemegang saham akan di maksimalkan dengan meminimalkan perbedaan antara nilai pasar ekuitas dengan ekuitas (modal sendiri) yang diserahkan ke perusahaan oleh para pemegang saham perusahaan). perbedaan ini disebut sebagai Market Value Added (MVA). Menurut Young \& O’Byrne, (2001:27) Oleh karena itu, jika nilai MVA tinggi menunjukkan perusahaan telah menciptkan kekayaan yang substansial bagi pemegang saham. MVA negatif berarti nilai dari investasi 
yang di jalankan manajemen kurang dari modal yang diserahkan kepada perusahaan oleh pasar modal yakni kekayaan telah di musnahkan.

Berdasarkan MVA dapat dibuat kontrak untuk menentukan besarnya bonus kinerja bagi pengelola. Masalahnya, MVA adalah ukuran kumulatif jangka panjang. Padahal bonus kinerja biasanya perlu dibayar tiap tahun. Sebagai pendekatan bagi penciptaan nilai setiap tahunnya, diperkenalkan konsep Economic Value Added (EVA) atau konsep nilai tambah ekonomis.

\section{Analisis Market Value Added (MVA)}

Market Value Added merupakan hasil kumulatif kinerja perusahaan yang dihasilkan oleh berbagai investasi yang sudah dilakukan maupun yang diantisipasi akan dilakukan.
Market Value Added (MVA) diformulasikan sebagai berikut:

MVA = Market of Equity - Equity Capital Suplied = Equity market Value Equity Book Value

Dimana masing-masing variabelnya diformulasikan sebagai berikut:

$\mathrm{EMV}=$ Number Share $x$ Price Per Share $E B V=$ Number Share $x$ Nomina Value Per Share

Perhitungan Market Value Added (MVA) merupakan selisih atau nilai buku saham, perusahaan dan nilai saham perusahaan di pasar saham. Sehingga saat disimpulkan bahwa MVA merupakan nilai EVA yang diharapkan perusahaan, namun tanpa memperhitungkan terlebih dahulu modal yang dipakai.

\section{Perhitungan Market Value Added (MVA)}

Berikut perhitungan Market Value Added (MVA) PT Bisi International Tbk. Tabel 15

Perhitungan MVA PT Bisi International Tbk. Tahun 2014-2018

\begin{tabular}{|c|c|c|c|c|c|c|}
\hline Keterangan & 2014 & 2015 & 2016 & 2017 & 2018 & Ket. \\
\hline $\begin{array}{ll}\text { Jumlah } & \text { Saham } \\
\text { Beredar } & \end{array}$ & 3.000 & 3.000 & 3.000 & 3.000 & 3.000 & $\begin{array}{l}\text { Dalam } \\
\text { Jutaan } \\
\text { Rupiah }\end{array}$ \\
\hline $\begin{array}{l}\text { Harga Saham } \\
\text { Per Lembar }\end{array}$ & 790 & 1.350 & 1.900 & 1.795 & 1.675 & Rupiah \\
\hline $\begin{array}{lr}\text { Nilai } & \text { Nominal } \\
\text { Saham } & \text { Per } \\
\text { Lembar } & \end{array}$ & 100 & 100 & 100 & 100 & 100 & Rupiah \\
\hline $\begin{array}{l}\text { EMV (Equity } \\
\text { Market Value) }\end{array}$ & 2.370 .000 & 4.050 .000 & 5.700 .000 & 5.385 .000 & 5.025 .000 & $\begin{array}{l}\text { Dalam } \\
\text { Jutaan } \\
\text { Rupiah }\end{array}$ \\
\hline $\begin{array}{l}\text { EBV (Equity } \\
\text { Book Value) }\end{array}$ & 79.000 & 135.000 & 190.000 & 179.500 & 167.500 & Rupiah \\
\hline $\begin{array}{l}\text { MVA (Market } \\
\text { Value Added) }\end{array}$ & 2.291 .000 & 3.915 .000 & 5.510 .000 & 5.205 .500 & 4.857 .500 & $\begin{array}{l}\text { Dalam } \\
\text { Jutaan } \\
\text { Rupiah }\end{array}$ \\
\hline
\end{tabular}

Sumber : Data diolah 
Dari hasil perhitungan MVA yang telah diolah pada PT Bisi International Tbk. maka dapat diketahui bahwa pada tahun 2014 PT Bisi International Tbk. pada tahun 2014 MVA sebesar Rp. 2.291.000.000.000 . pada tahun 2015 PT Bisi International Tbk. MVA sebesar Rp.3.915.000.000.000 terjadi perubahan sebesar 41,4\%, pada tahun 2016 perusahaan memiliki MVA sebesar Rp. 5.510.000.000 adanya perubahan sebesar $28,9 \%$, dan pada tahun 2017 MVA sebesar Rp.5.205.500.000.000 mengalami perubahan $-5,84 \%$ dan 2018 PT Bisi International Tbk. mendapatkan MVA sebesar Rp.4.857.500.000.000 adanya perubahan sebesar 7,16\%. Adanya perubahan dalam 5 tahun periode hal ini dikarenakan adanya perubahan dalam harga saham setiap tahunnya.

\section{Kesimpulan dan Saran}

\section{Kesimpulan}

1. Kinerja keuangan pada PT Bisi International Tbk, jika dihitung menggunakan metode EVA (Economic Value Added) pada periode 5 tahun terakhir bernilai positif hal ini mencerminkan bahwa PT Bisi International Tbk, sudah mampu mendapatkan nilai tambah ekonomis bagi perusahaan.

2. Kinerja keuangan PT Bisi International Tbk, menggunakan metode MVA pada periode 5 tahun terakhir bernilai positif dilihat dari hasil masing-masing pertahun perusahaan MVA yang positif (MVA>0) maka diartikan perusahaan dapat memberikan nilai tambah pasar pada perusahaan serta memberikan kekayaan bagi investor

\section{Saran}

Saran yang dapat diberikan adalah yang dihitung menggunakan metode EVA dan MVA pada perusahaan PT Bisi International $\mathrm{Tbk}$, memiliki nilai positif $(\mathrm{EVA}>0)$ dan $(\mathrm{MVA}>0)$. Bagi investor, untuk mendapatkan keuntungan yang baik maka investor harus mengetahui informasi kinerja keuangan perusahaan guna untuk mempertimbangkan keputusan untuk berinvestasi. Dari penelitian ini perusahaan PT Bisi International Tbk, memiliki nilai MVA yang positif dari periode 2014-2018. Perusahaan tetap mempertahankan serta meningkatkan kinerja setiap tahunnya khususnya pada kinerja keuangan agar kepercayaan pasar terhadap perusahaan semakin meningkat. Perusahaan juga terus meningkatkan laba operasional tanpa adanya tambahan dana melainkan mengoptimalkan dengan menggunakan asset perusahaan serta mengefisiensikan penggunaan biaya-biaya operasional untuk mendapatkan laba yang baik. Sehingga dengan hal ini perusahaan dapat meningkatkan laba yang terus meningkat pada setiap tahunnya. 


\section{Daftar Pustaka}

Brigham, E. F., \& Houston, J. F. (2006). Dasar-dasar Manajemen Keuangan (10 ed.). Jakarta: Salemba Empat.

Husnan, S., \& Pudjiastuti, E. (2004). Dasar-dasar Manajemen Keuangan (Edisi Keempat). Yogyakarta: UPP STIM YKPN.

Husnan, S., \& Pudjiastuti, E. (2015). Dasar-dasar Manajemen Keuangan (Edisi Ketujuh). Yogyakarta: UPP STIM YKPN.
Rahardjo, B. (2005). Laporan Keuangan Perusahaan. Yogyakarta: Gadjah Mada University Press.

Rudianto. (2006). Informasi Untuk Pengambilan Keputusan Manajemen. Jakarta: PT. Gramedia Widiarsarana Indonesia.

Young, D. S., \& O'Byrne, S. F. (2001). EVA \& Manajemen Berdasarkan Nilai. Jakarta: Salemba Empat. 